Dnopreichuk D., Stefanov V.

\title{
RESEARCH OF THE WEAR RESISTANCE OF MULTI-COMPONENT BRONZE IN THE CONDITIONS OF THE HYDRAULIC OIL PROCESSED BY THE POWER FIELD
}

Об’єктом дослідження є процес зміни зносостійкості бронзи в умовах електростатичного оброблення гідравлічної оливи. Зносостійкість бронзових елементів пар тертя визначає ресурс аксіально-плунжерних насосів і впливає на їх основні характеристики «подача - тиск».

Проведення досліджень базувались на теорї планування експериментів та статистичних методах обробки результатів випробувань. Методика досліджень передбачала моделювання процесу тертя ковзання за допомогою пари тертя «колодка - ролик» на машині тертя СМЦ-2 (країна виробник СРСР, модернізаціл Україна). Саме такий вид тертя має місие в трибосистемі «плунжер - блок ииліндрів», «розподільний диск блок ииліндрів». Також методикою передбачалось попереднє оброблення гідравлічної оливи електростатичним полем в пристрої з подальшою подачею в ємність з роликом за допомогою насосної станції. Варіювались два незалежних фактори:напруженість електростатичного поля та напращювання гідравлічної оливи. Незмінними факторами залишались швидкість потоку гідравлічної оливи в пристрої, температура гідравлічної оливи, тиск у контакті, лінійна швидкість ковзання ролика та час проведення кожного випробування.

Отриманні експериментальні дані дозволили встановити закономірність, що характеризує процес тертя ковзання за впливу на гідравлічну оливу силового поля. Дана закономірність розкриває вплив напруженості електростатичного поля та напращювання гідравлічної оливи на зносостійкість бронзової колодки, що випробовувалась на машині тертя СМЦ-2. Це дало можливість визначити рачіональні значення параметрів електростатичного поля, за яких досягається максимальна зносостійкість бронзи в залежності від на-

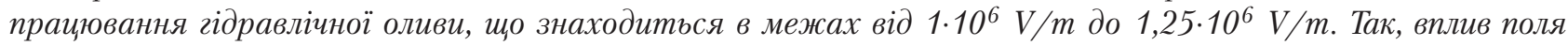
на оливу сприяє підвищенню зносостійкості бронзи до 5 разів за умов гідравлічної оливи в стані поставки та до 3 разів при оливі з часом напращювання 2000 год. Вплив поля призводить до поляризаційних ефектів в оливі, які сприяють утворенню квазікристалічних плівок на поверхні тертя, збільшуючи зносостійкість трибосполучення.

Ключові слова: гіӘравлічна олива, електростатичне поле, зносостійкість бронзи, трибосполучення, пара тертя, колодка-ролик.

Received date: 28.01.2020

Accepted date: 27.02 .2020

Published date: 30.04 .2020
Copyright (C) 2020, Onopreichuk D., Stefanov V. This is an open access article under the CC BY license (http://creativecommons.org/licenses/by/4.0)

\section{Introduction}

Widespread use in the production of hydraulic machines has received such a structural material as bronze. In particular, in piston machines (for example, in axialplunger pumps) the most critical elements are made of it (bronze): plunger support shoes, hydraulic cylinder blocks. It is these elements that work in friction pairs «support shoe - plunger», «plunger - cylinder block», «distribution disk - cylinder block», which are the ones that determine the life of an axial plunger pump (APP). This is due, for example, to the fact that the wear rate of the friction pairs «plunger - cylinder block» affects the main characteristics of the APP, such as «feed - pressure». They determine the volumetric efficiency coefficient (Efficiency), which regulates the life of the pump $15 \%$ drop from the nominal value. Therefore, a decrease in the wear rate of the above friction pairs makes it possible to increase the service life of this type of pump.
Such a question has several directions of solution. One of them is the introduction of new approaches to design and construction through the prism of in-depth research and the establishment of new patterns in the work of structural elements, where the goal is to increase the efficiency of pumps $[1,2]$. The second direction involves the application of an additional layer of antifriction material on the most critical elements of the pump friction pairs in order to increase their wear resistance [3-5]. Indeed, in such tribological processes, friction occurs between the soft material bronze and steel. It is the rapid wear of parts made of bronze that determines the life of the entire hydraulic machine. Compared with the previous areas, the implementation of which is possible only at the stage of design, design and manufacture of APP, the following can be implemented during operation of the pump. It consists in improving the tribological properties of hydraulic oils by adding various kinds of additive packages to them $[6,7]$ or by the influence of external 
force fields [8]. From the point of view of the physics of the process of formation of a lubricating film on friction surfaces, additive packages do not fully fulfill their functional purpose $[9,10]$. That is why, in an expedient and promising way to improve the formation of a lubricating film with improved antifriction properties, the effect on the molecules of additives and basic molecules of hydraulic oil of external force fields [11-13]. Both magnetic and electrostatic fields belong to force fields, but from the point of view of controlling friction processes, it is advisable to use an electrostatic field [12]. Thus, the establishment of dependences of the wear resistance of bronze over time, from which the elements of friction pairs of hydraulic machines are made from the parameters of the electrostatic field, is an urgent task. The object of research is the process of changing the wear resistance of bronze under the conditions of electrostatic treatment of hydraulic oil. The aim of research is to establish patterns of change in the wear resistance of multicomponent bronze in the conditions of hydraulic oil treated with a force field.

\section{Methods of research}

The wear resistance of friction pairs depends on the nature of the friction surfaces, hydraulic grease and its temperature, load conditions, the relative sliding speeds of the surfaces and the temperature of the friction surfaces at the contact points. A friction pair realizes the contact of surfaces in a plane. In this regard, wear tests were carried out on the SMC-2 friction machine (the country is the manufacturer of the USSR, Ukraine is modernized), where a «block - roller» friction pair was used as the obtained test material. The materials of the samples (roller and block) were selected according to the materials used in APP 321.224. The block material is multicomponent bronze Бр.АЖ 9-4, and the roller is 38X2MЮA alloy steel. The surface roughness of the block and roller was selected on the basis of the design documentation for the specified pump, thereby ensuring the necessary actual contact area.

Fig. 1 shows a diagram of a laboratory setup for testing wear resistance using a friction machine.

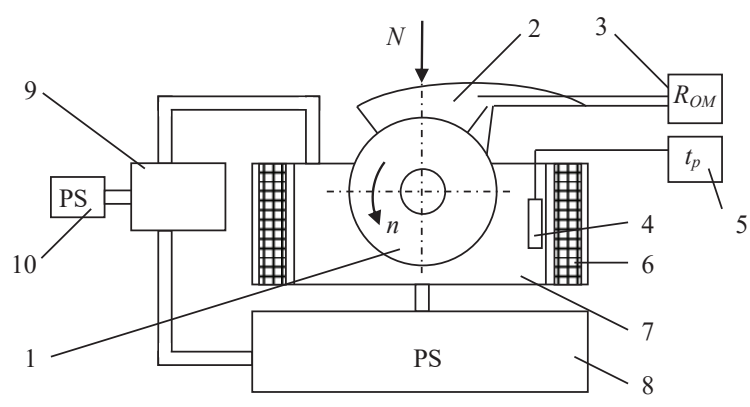

Fig. 1. Scheme of a laboratory unit for testing the wear resistance of a «block - roller» friction pair on a friction machine SMC-2: 1 - raller; 2- block; 3 - ohmmeter $\left(B_{O M}\right)$; 4 - temperature sensor; 5 - controller $\left(t_{p}\right)$; 6 - heating element; 7 - capacity; 8 - pumping station (PS); 9 - device for processing hydraulic oil; 10 - power supply unit (PSU); $N$ - external load

The frequency of rotation of the roller 1 and the pressing force of the block 2 are regulated and supported by the controls of the friction machine. The prepared hydraulic oil is supplied at a speed of $6 \mathrm{~m} / \mathrm{s}$ using a pumping station 8 through an oil processing device into friction pairs [14].
The field strength of the oil processing is advisable in the range of $0.5-1.5 \cdot 10^{6} \mathrm{~V} / \mathrm{m}$ [14].

The studies used multigrade thickened hydraulic oil, which corresponds to TU 38-1-281-69. The oil was used both in the delivery state and with different operating hours, so it was necessary to control the purity class of each of the samples. The quantity and size distribution of mechanical particles suspended in hydraulic oil was determined by the photometric method using an FS-112m analyzer of mechanical impurities (country of origin USSR).

According to the measurement results, according to GOST 17216-2001, the purity class of hydraulic oil samples was established (Table 1).

Table 1

Cleanliness class of hydraulic oil samples taken for research

\begin{tabular}{|c|c|c|}
\hline $\begin{array}{c}\text { No. of } \\
\text { sample }\end{array}$ & $\begin{array}{c}\text { Operating } \\
\text { hours, h }\end{array}$ & $\begin{array}{c}\text { Cleanliness class according } \\
\text { to G05T 17216-2001 }\end{array}$ \\
\hline 1 & 0 & 9 \\
\hline 2 & 500 & 12 \\
\hline 3 & 1000 & 13 \\
\hline 4 & 1500 & 13 \\
\hline 5 & 2000 & 15 \\
\hline
\end{tabular}

During the operation of axial-plunger pumps, the lubrication type of the «plunger-sleeve» junction periodically changes from hydrodynamic to ultimate, and vice versa. This is due to a change in the linear velocity of the plunger from about 10 to $0 \mathrm{~m} / \mathrm{s}$ at the dead center and a sharp increase in contact pressure of about $20 \mathrm{MPa}$ (there is a transition to ultimate lubrication).

The transition point to the regime of maximum lubrication of the samples was determined by measuring the electrical resistance. For this, after electrical isolation of the samples from the «earth», an ohmmeter was connected to them and, during hydrodynamic lubrication, the resistance of the moving contact of the samples was more than 1 MOhms. In the transition to the limit $-0.2-1$ Ohms. As a result of a combination of contact pressures and velocities, as well as an analysis of the resistance of the lubricated contact of the samples, contact pressure and velocity were established at which a transition from the limiting lubrication of the friction pair to hydrodynamic takes place.

Thus, the values of all constant factors were established:

- flow rate of hydraulic oil in the device $-6 \mathrm{~m} / \mathrm{s}$;

- temperature of the hydraulic oil in the tank of the

pumping station $-70{ }^{\circ} \mathrm{C}$;

- pressure in contact - $8 \mathrm{MPa}$;

- linear roller sliding speed $-0.3 \mathrm{~m} / \mathrm{s}$;

- time of one test, $t=1$ hours.

Based on the theory of experimental design and methods of statistical processing of measurement results, an orthogonal plan for a 2-factor experiment was developed (Table 2).

The wear resistance of the blocks was determined by recalculating the weight wear. That is, with the help of analytical scales VLR-200 (the country is the manufacturer of the USSR) with an error of not more than $0.01 \mathrm{~g}$, the weight loss of the block was estimated during the test, and then it was listed by the expression:

$$
Z=\frac{1}{V_{Z}}
$$

where $V_{Z}$ - the weight wear of the roller in one hour, $\mathrm{mg} / \mathrm{h}$. 
Orthogonal plan for two-factor experiment

\begin{tabular}{|c|c|c|c|c|}
\hline \multirow{2}{*}{ No. } & \multicolumn{2}{|c|}{ Coded values } & \multicolumn{2}{|c|}{ Natural values } \\
\cline { 2 - 5 } & $X_{1}$ & $X_{2}$ & $\begin{array}{c}\text { Hydraulic oil operating } \\
\text { hours, } t, \mathrm{~h}\end{array}$ & $\begin{array}{c}\text { Electrostatic field } \\
\text { strength, } E \cdot 10^{6} \mathrm{~V} / \mathrm{m}\end{array}$ \\
\hline 1 & 0 & 1 & 1000 & 1.5 \\
\hline 2 & 1 & 0 & 2000 & 1 \\
\hline 3 & -1 & -1 & 0 & 0.5 \\
\hline 4 & -1 & 0 & 0 & 1 \\
\hline 5 & 1 & 1 & 2000 & 1.5 \\
\hline 6 & 0 & -1 & 1000 & 0.5 \\
\hline 7 & 1 & -1 & 2000 & 0.5 \\
\hline 8 & -1 & 1 & 0 & 1.5 \\
\hline 9 & 0 & 0 & 1000 & 1 \\
\hline
\end{tabular}

\section{Research results and discussion}

The results of experimental studies are given in Table 3 .

Table 3

The results of experimental studies to determine the wear resistance of a bronze block from electrostatic field strength and hydraulic oil operation

\begin{tabular}{|c|c|c|c|c|c|c|c|c|c|}
\hline \multicolumn{1}{|c|}{ No. } & 1 & 2 & 3 & 4 & 5 & 6 & 7 & 8 & 9 \\
\hline $\begin{array}{l}\text { Wear } \\
\text { resistance } \\
Z, \mathrm{~h} / \mathrm{mg}\end{array}$ & 1.300 & 0.803 & 0.958 & 2.867 & 0.775 & 0.722 & 0.413 & 1.576 & 1.821 \\
\hline
\end{tabular}

Based on the results of the studies, the regression equations are obtained that describe the pattern of wear resistance of the bronze block of a «block - roller» friction pair depending on the selected factors:

$$
\begin{aligned}
& Z=0.613-0.00081 \cdot t+2.9272 \cdot E- \\
& -0.00000001 \cdot t^{2}-1.4012 \cdot E^{2}-0.00019 \cdot t \cdot E,
\end{aligned}
$$

where $t$ - the operating time of the hydraulic oil, hours; $t-$ the electrostatic field strength.

A graphical representation of the results of tests of the effect of electrostatic treatment of hydraulic oil on the change of wear resistance of a bronze block of a «block roller» friction pair with different generation of hydraulic oil on the SMC-2 machine is shown in Fig. 2 and Fig. 3.

The research results show that with an increase in the operating time of hydraulic oil, wear resistance nonlinearly comes for both untreated and processed hydraulic oil, Fig. 2. The option of untreated hydraulic oil wear resistance decreases from $0.65 \mathrm{~h} / \mathrm{mg}$ up to $0.31 \mathrm{~h} / \mathrm{mg}$, that is, more than 2 times for a period of 2000 hours (Fig. 2, blue curve). For a variant of hydraulic oil treated with an electrostatic field, the external field strength also affects the decrease in wear resistance over time. So, when the external field strength is $0.5 \cdot 10^{6} \mathrm{~V} / \mathrm{m}$, the wear resistance decreases by 2.3 times in 2000 hours (Fig. 2, red curve). And at a field strength of $1.5 \cdot 10^{6} \mathrm{~V} / \mathrm{m}$, wear resistance decreases by 2 times (Fig. 2, yellow curve). In general, comparisons of the curves in Fig. 2 shows that the use of electrostatic treatment of hydraulic oil increases the wear resistance of bronze up to 5 times with hydraulic oil in the delivery state and up to 3 times for the liquid used up.

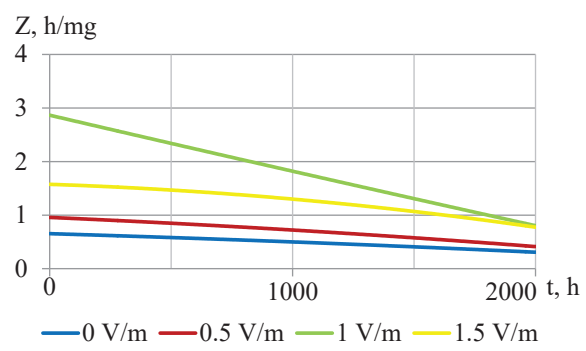

Fig. 2. The change in the wear resistance of the bronze blocks depending on the operating time of the hydraulic oil under various processing conditions

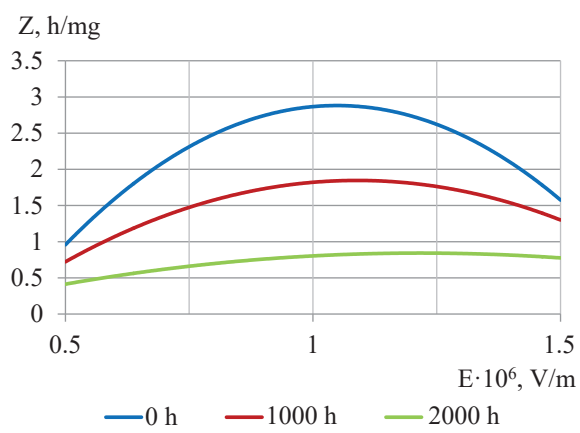

Fig. 3. The change in the wear resistance of the bronze blocks depending on the intensity of the electrostatic field with different operating times

About the results of changing the wear resistance of a bronze block depending on the electrostatic tension, then in accordance with Fig. 3 for any operating time of hydraulic oil, an increase in the field strength leads to an increase in wear resistance to some extent. And with a subsequent increase in field strength, wear resistance decreases. That is, the function of wear resistance from field strength in the entire studied range has a maximum, and with an increase in the operating time of hydraulic oil, such a maximum shifts to the region of large field strengths. So, for hydraulic oil in the delivery state, the maximum function occurs at a tension of $1.05 \cdot 10^{6} \mathrm{~V} / \mathrm{m}$, and for hydraulic oil with a running time of 2000 hours at a tension of $1.24 \cdot 10^{6} \mathrm{~V} / \mathrm{m}$.

Such results are due to the fact that under the influence of an electrostatic field polarization of hydraulic oil occurs. The additive molecules under such conditions, due to the constant dipole moment, are oriented in the direction of the field strength, being rebuilt into comfortable monomers, dimers and macrodipoles. The base oil molecules, in contrast to the additive molecules, are nonpolar dielectrics and, under the influence of the field, acquire a dipole moment, which allows them to interact with the additive molecules to form an additionally directed layer along the field strength vector. This allows, taking into account the physical competitive adsorption, to create a quasicrystalline layer on the friction surface. With the accumulation of hydraulic oil, wear products appear in the volume, which, under the action of the electrostatic field, acquire a local field around them that exceeds the external one. This allows the additive molecules to be adsorbed onto the surface of the wear product, forming a polymolecular layer. The control of such supramolecular 
structures requires an increase in the electrostatic field strength, which explains the shift of the maximum of the wear resistance function to the region of large field strengths (Fig. 3). Supramolecular structures from wear products and additive molecules, under the influence of an external field, fill the microdepressions of the friction surface, contributing to an increase in the actual contact area and the formation of a boundary layer. This leads to a uniform distribution of the external load and, as a result, a decrease in specific pressure, and therefore an increase in the wear resistance of the bronze block.

\section{Conclusions}

Experimental studies have established that the treatment of hydraulic oil with an electrostatic field helps to increase the wear resistance of bronze. So, under the conditions of operation of hydraulic oil in the delivery state, the wear resistance of bronze increases up to 5 times, and with oil with an operating time of 2000, up to 3 times. It was also established the pattern of changes in the wear resistance of the bronze blocks from the electrostatic field, affects the hydraulic oil and the operating time of the hydraulic oil. This made it possible to determine the rational values of the parameters of the electrostatic field at which the maximum wear resistance of bronze is achieved depending on the operating time of hydraulic oil, from $1 \cdot 10^{6} \mathrm{~V} / \mathrm{m}$ to $1.25 \cdot 10^{6} \mathrm{~V} / \mathrm{m}$.

\section{References}

1. Bergada, J., Sushil, K., Watton, J. (2012). Axial Piston Pumps, New Trends and Development. Published by Nova Science USA.

2. Hong, Y. S. (2012). Investigation into design problems of hydrostatic slipper bearings for variable speed axial piston pumps. Journal of The Korean Society for Fluid Power \& Construction Equipments, 9.

3. Hong, Y.-S., Lee, S.-Y. (2008). A Comparative Study of Cr-X-N $(\mathrm{X}=\mathrm{Zr}, \mathrm{Si}$ ) Coatings for the Improvement of the Low-Speed Torque Efficiency of a Hydraulic Piston Pump. Metals and Materials International, 14 (1), 33-40. doi: http://doi.org/10.3365/ met.mat.2008.02.033

4. Hong, Y. S., Kim, J. H., Lee, S. L. (2014). Performance Improvement of a Swash Plate Type Piston Pump in the Low-Speed Range by a DLC Coating. Journal of The Korean Society for Fluid Power \& Construction Equipments, 11 (4), 25-31. doi: http:// doi.org/10.7839/ksfc.2014.11.4.025
5. Dovbenko, M. N., Evdokimov, V. D. (2014). Development of unconventional ways to improve performance of the axial piston hydromashines taking into account repair abilities. EasternEuropean Journal of Enterprise Technologies, 5 (7 (71)), 31-36. doi: http://doi.org/10.15587/1729-4061.2014.27996

6. Ermakov, S. F. (2012). Effect of lubricants and additives on the tribological performance of solids. Part 2. Active friction control. Journal of Friction and Wear, 33 (3), 217-223. doi: http:// doi.org/10.3103/s106836661203004x

7. Dmitrichenko, N. F., Milanenko, A. A., Savchuk, A. N., Bilyakovich, O. N., Turitsa, Y. A., Pavlovskiy, M. V., Artemuk, S. I. (2016). Improving the efficiency of lubricants by introducing friction modifiers for tracked vehicles under stationary conditions of friction. Journal of Friction and Wear, 37 (5), 441-447. doi: http://doi.org/10.3103/s1068366616050044

8. Mohamed, M. K., Alahmadi, A., Ali, W. Y., Abdel-Sattar, S. (2012). Effect of Magnetic Field on The Friction and Wear Displayed by The Scratch of Oil Lubricated Steel. International Journal of Engineering \& $\mathcal{F}$ Technology, 12 (6), 137-143.

9. Lysikov, Ye. M., Onopriichuk, D. V. (2010). Pidvyshchennia resursu tekhnichnykh system MVS Ukrainy shliakhom vykorystannia nanotekhnolohii. Zbirnyk naukovykh prats Akademii vnutrishnikh viisk MVS Ukrainy, 1 (15), 34-37.

10. Lysikov, Ye. M., Voronin, S. V., Stefanov, V. O. (2006). Balans PAR v robochykh ridynakh hidropryvodiv budivelnykh ta koliinykh mashyn. Zbirnyk naukooykh prats UkrDAZT, 73, 84-89.

11. Abeer, A. E., Abo Ainin, H. M., Khashaba, M. I., Ali, W. Y. (2011). Effect of Magnetic Field on Friction and Wear of Brass. Journal of the Egyptian Society of Tribology, 8 (2), 16-30.

12. Voronin, S. V. Dunaev, A. V. (2015). Effects of electric and magnetic fields on the behavior of oil additives. Journal of Friction and Wear, 36 (1), 33-39. doi: http://doi.org/10.3103/ s1068366615010158

13. Simdyankin, A. A., Uspensky, I. A., Pashchenko, V. M., Starunsky, A. V. (2017). Ultrasonic machining of engine lubricating oil during tribotechnical testing. Journal of Friction and Wear, 38 (4), 311-315. doi: http://doi.org/10.3103/s1068366617040134

14. Onopreichuk, D. V. (2011). Vplyv napruzhennia elektrostatychnoho polia na tovshchynu mastylnoi plivky $\mathrm{v}$ hidropryvodi pry hranychnomu terti. Zbirnyk naukooykh prats UkrDAZT, 122, 282-288.

Onopreichuk Dmytro, PhD, Associate Professor, Department of Construction, Track and Handling Machines, Ukrainian State University of Railway Transport, Kharkiv, Ukraine, ORCID: http:// orcid.org/0000-0002-6314-3936,e-mail:dmytroonopriychuk@ukr.net

Stefanov Volodymyr, PhD, Associate Professor, Department of Construction, Track and Handling Machines, Ukrainian State University of Railway Transport, Kharkiv, Ukraine, ORCID: http://orcid.org/ 0000-0002-7947-2718,e-mail:vstef@ukr.net 